Bol. Acad. peru. leng. 47. 2009 (133-137)

\title{
CELEBRANDO LOS 90 AÑOS DE UN COLEGA
}

\author{
Luis Jaime Cisneros \\ Academia Peruana de la Lengua
}

Así como afianzan la certidumbre de que Saussure nos es todavía imprescindible punto de partida para descubrirnos creadores de lenguaje, razonamiento a que nos convidan hoy los textos antiguos recién descubiertos en Europa. Si hoy me invitan a 'pensar' en homenaje a Francisco Miró Quesada, debo recurrir a esta costumbre, ya arraigada a lo largo de años y lecturas, de particularizar y generalizar a que nos ha ido acostumbrando la tarea docente.

Si me sugieren pensar en español, siento que me están proponiendo una reiteración anclada en el absurdo. Si se trata de 'pensar', me veo convocado a generar significados para, así, demostrar que pienso. Seguramente, deberé admitir que tengo un viejo pleito con el mundo de la significación. A veces, me doy con gente que si no oye bien, no comprende. Y a veces, también, tropiezo con quienes, sin haber sido lectores de Searle, incurren en preguntas que también aprendí a plantear a mis estudiantes años atrás:

"¿Cuál es la diferencia entre decir algo queriendo decirlo significativamente y decirlo no queriendo decirlo significativamente?" (Actos de habla, Madrid, Cátedra, 2000, p. 13). 
Reconozco en seguida que estas preguntas siguen ahí vigentes, generando situaciones diversas, que suelen ser pasto del sarcasmo y el cubileteo político. Sí, es verdad; el significado nos es tan necesario como la verdad, y cada día se nos hace más imperioso analizarlo, defenderlo, en la medida en que cada día nos es más urgente quebrar la soledad y comunicarnos con el prójimo. Hablar es, en el fondo, significar; alguna razón asiste a Searle cuando afirma que:

"El acto de habla realizado al emitir una oración es una función del significado de la oración” (ibid, 27).

Y si para hablar y 'significar' requerimos el auxilio de la palabra, quizá convenga enfrentarnos con ella. Me valgo de la afirmación de Foucault de que cabía a la palabra representar el pensamiento:

"Representar es oír en el sentido estricto: el lenguaje representa el pensamiento, como éste se representa a sí mismo [...] Así, pues, las palabras no forman la más mínima película que duplique el pensamiento por el lado de la fachada: lo recuerdan, lo indican, pero siempre desde el interior, entre todas esas representaciones que representan otras [...] No es un efecto exterior del pensamiento, sino pensamiento en sí mismo" (Las palabras y las cosas, México, Siglo XXI, 1971, 83).

En el libro tercero de su Physica, Aristóteles trata del movimiento. Nos propone, como esquema esencial, los tres momentos para considerar la dynamis, la enérgeia, el érgon. De alguna manera podríamos pensar que Humboldt la tuvo en cuenta cuando destacó la importancia de su Sprachtätigkeit. Quiero aprovechar el planteamiento aristotélico para, apoyado en algunas ideas de Gustave Guillaume, acogerme todavía al indispensable Heidegger. A lo largo de la enérgeia, el emisor va realizando una doble operación, en el curso de la cual se va prefigurando la estructura de la frase. Por un lado está entregado a la tarea de asignarle presencia fónica a las ideas que debe transmitir; de otro lado, y simultáneamente, debe asegurarse de que el modo elegido por él sea suficientemente significativo para que el receptor pueda comprender el texto. En suma, debe producir 
una cadena sonora que le permita a la persona a quien va destinada enterarse del contenido. Contenido y expresión fueron los términos elegidos por Hiemslev. Guillaume nos sugiere no desatender a este periodo en que el hablante se ve respaldado históricamente por su tradición y, silenciosa pero conscientemente, se entrega al singular trabajo de elegir los elementos lingüísticos destinados a revelar lo que piensa. Combina sonidos nutridos de significado apenas se vayan encadenando los unos con los otros. A ese momento, dueño como soy de mi mundo interior, dedico mi competencia lingüística. Durante ese proceso tengo presente ciertamente no solamente lo que quiero y debo decir, sino lo que quiero que comprenda mi oyente. Ese largo proceso constituye lo que Guillaume llama el tiempo operativo. Terminado ese proceso, mi responsabilidad ha cesado. Expuestas así las cosas, y testigo como he sido de muchas situaciones, me veo obligado a plantearme algunas inquietudes:

¿Es verdad que mi oyente comprende cuando oye lo que le digo? ¿Basta que yo diga, en tono suficiente de voz, para que me oiga, y me aseguro así que ha comprendido? Y me pregunto si cuando afirma haberme oído, ha comprendido lo que dije (que es lo que oyó), y no siempre lo que le 'quise decir'. Heidegger ha llamado al respecto la atención:

"La relación del habla con el comprender y la comprensibilidad resulta clara si se fija la atención en una posibilidad existenciaria inherente al habla misma, al oír. No es casual que digamos, cuando no hemos oído 'bien', que no hemos 'comprendido'. El oír es constitutivo del hablar. Y así como la fonación verbal se funda en el habla, la percepción acústica lo hace en el oír [...] El 'ser ahí' oye porque comprende" (Ser y tiempo, 182).

Pero ciertamente este 'oír' implica un auscultare. Un oír en profundidad asegura la comunicación y nos ofrece la esencia de lo conversado. "¿Qué es lo que me quieres decir con eso?” anuncia que hemos oído lo exteriormente expuesto, pero que reconocemos una voluntad de no haber sido claro. Pero solamente el competente que sabe escuchar alcanza a advertir situaciones como éstas. Yo aprovecho a veces para interrogar al respecto a mis amigos psicoanalistas, siempre preocupados por lo que 'dice' el paciente. Siempre 
dice lo 'que quiere decir', o a veces no. ¿Le interesa al terapeuta el lento y madurado proceso de la enérgeia, durante el cual el paciente va elaborando la arquitectura de su frase, o solamente le importa el texto resultante, que no da cuenta de las vacilaciones y las dudas, de los embates a que se han tenido que hacer frente a ideas, palabras, intenciones?

Claro es que esos son problemas a que nos obliga a enfrentar el significado. Si no acierto con el significado, no puedo enterarme del pensamiento ajeno. Pero para acertar con el significado (que transmite lo que pienso) debo acudir a la palabra (para que sea interpretada por quienes deben comprender mi significado). Y este es el dilema en que vive mucha gente confundida. ¿Está el pensamiento relacionado con la palabra necesariamente, pero esa relación exige la presencia del significado? Leo en los papeles de Saussure recientemente descubiertos y muy anteriores a la edición del Cours de linguistique générale:

"Se comete el error de creer que hay una palabra como por ejemplo voir que existe en sí. Una significación, que es la cosa asociada a esa palabra [...] Es decir, que es la propia asociación la que hace la palabra, y que fuera de ella ya no hay nada. La mejor prueba es que wuar en otra lengua tendría otro sentido, en consecuencia no es nada en sí; y en consecuencia sólo es una palabra en tanto que evoca un sentido. Pero, comprendido esto, queda perfectamente claro que no se debe dividir y admitir por una parte la palabra y por otra su significación. Juntas constituyen un todo" (Ecrits de linguistique générale, París, Gallimard, 2002, 93).

Qué bien advitió Heidegger este vínculo raigal existente entre el significar y el comprender:

"Hablar es articular 'significativamente' la comprensibilidad del 'ser en el mundo', al que es inherente el 'ser con' y que se mantiene en cada caso en un modo determinado del 'ser uno con otro' (Ser y tiempo, ed. J. Gaos, 180). 
En estos compromisos a que nos convoca el tiempo operativo, vamos los hablantes diseñando el esquema a que ha de verse sometido el pensamiento para ser ofrecido al oyente. En ese trajín vamos obligadamente discerniendo en las cosas para acabar luego acudiendo a una operación orientada a la comprensión que le garantice apropiada fisonomía al pensamiento en el terreno del oyente. Guillaume nos propuso algunas pruebas, y elijo acá la de Correr y carrera. Desde la escuela venimos aceptando la distinción: correr, verbo; carrera, sustantivo. En el plano de la noción discernida, no hay diferencia alguna. En ambas voces reconocemos la idea de movimiento e intuimos la de un proceso determinado.

"Pero esta idea de movimiento que les es común, y las expone para expresar una operación idéntica de discernimiento, implica, a su vez, según la perspectiva en que se coloca el espíritu, en sí mismo, una operación de entendimiento que o bien concluye en el tiempo (y resulta el verbo correr) o bien concluye en el espacio (y resulta el sustantivo carrera)" (II, 23).

El sistema de una lengua no procede directamente de la noción discernida, sino de aquello que el discernimiento de las nociones implica, en seguida, un entendimiento generalizador y clasificador independiente de la noción discernida. La noción es la misma en correr y en carrera. Pero para una misma operación de discernimiento, tenemos a la vista la facultad de recurrir a dos operaciones diferentes en entendimiento final. 